\title{
NINTH ANNUAL LIST OF PAPERS
}

READ BEFORE THE AMERICAN MATHEMATICAL SOCIETY AND

SUBSEQUENTLY PUBLISHED, INCLUDING REFERENCES TO

THE PLACES OF THEIR PUBLICATION.

ALEY, R. J. A Triangle Related to Nagel's Triangle. Read (Chicago) April 9, 1898. Proceedings of the Indiana Academy of Science, 1898, pp. 89-91.

A New Set of Three Collinear Points Connected with a Triangle. Read (Chicago) Dec. 28, 1899 Bulletin of the American Mathematical Society, vol. 6, No. 5, p. 193 ; Feb., 1900.

Benner, H. Bestimmung der Coefficienten welche hei der Berechnung der Integrale $\int \frac{x^{n} d x}{\sqrt{1+a x+b x^{2}}}$ und $\int \frac{x^{n} d x}{\sqrt{1+a x+b x^{2}+c x^{3}}}$ auftreten. Read (Chicago) Dec. 31, 1897. Doctor Dissertation, University of Erlangen, 1897, pp. 57. Boston, Ginn and Company, 1899.

BAKer, A. L. Fundamental Algebraic Operations. Read Aug. 19, 1898. Proceedings of the Rochester Academy of Science, vol. 3, p. 162.

BLAKE, E. M. Linear Euthymorphic Functions of the First Order. Read (Chicago) Dec. 31, 1896. Proceedings of the Indiana Academy of Science. 1896, pp. 87-88.

- The Ellipsograph of Proclus. Read (Chicago) Dec. 31, 1897, and April 9, 1898. American Journal of Mathematics, vol. 22, No. 2, pp. 146-153; A pril, 1900.

- On the Ruled Surfaces Generated by the Plane Movements whose Centrodes are Congruent Conics Tangent at Homologous Points. Read A ug. 19, 1898. American Journal of Mathematics, vol. 21, No. 3, pp. $257-269$; July, 1899.

BôCHER, M. On Regular Singular Points of Linear Differential Equations of the Second Order whose Coefficients are not Necessarily Analytic. Read Dec. 28, 1899. Transactions of the American Mathematical Society, vol. 1, No. 1, pp. 40-52 ; Jan., 1900.

- Some Theorems Concerning Linear Differential Equations of the Second Order. Read Feb. 24, 1900 Bulletin of the American Mathematical Society, vol. 6, No. 7, pp. 279-280 ; A pril, 1900.

BoLzA, O. The Elliptic Sigma-Functions Considered as a Special Case of the Hyperelliptic Sigma-Functions. Read (Chicago) Dec. 28, 1899. Transactions of the American Mathematical Society, Vol. 1, No. 1, pp. 53-65 ; Jan., 1900.

BRown, E. W. On the Particular Integrals of Linear Differential Equations, and Their Application to the Lunar Theory. Read Mar. 28, 1896. Cambridge Philosophical Transactions, vol. 18, pp. 94-106 ; 1899.

- On Tide Currents in Estuaries and Rivers. Read Apr. 29, 1899. Annals of Mathematics, 2d series, vol. 1, No. 2, pp. 68-70 ; Jan., 1900. 
CAJori, F. Notes on the History of Logarithms. Read Aug. 25, 1899. Zeitschrift für Mathematik und Physik, vol. 44, supplement: Abhandlungen zur Geschichte der Mathematik, vol. 14, No. 9. pp. 31-39; 1899.

CAMpreld, D. F. On Linear Differential Equations of the Third and Fourth Orders in whose Solutions Exist Certain Homogeneous Relations. Read Feb. 25, 1899. Quarterly Journal of Mathematics, vol. 31, No. 122, pp. 161-192 ; Sept., 1899.

Campbell, J. E. On the Types of Linear Partial Differential Equations of the Second Order in Three Independent Variables Which are Unaltered by the Transformations of a Continuous Group. Read Dec. 28, 1899. Transactions of the American Mathematical Society, vol. 1, No. 2, pp. 243-258; A pril, 1900.

Chessin, A. S. On Relative Motion. Read Aug. 19, 1898, Oct. 29, 1898, and Aug. 25, 1899. Transactions of the American Mathematical Society, vol. 1, No. 2, pp. 116-169 ; A pril, 1900.

- On the Development of the Perturbative Function in Terms of the Eccentric Anomalies. Read Dec. 28, 1898 Astronomical Journal, No. 446, vol. 20, No. 10, pp. 73-76 ; July 22, 1899.

Coolidge, J. L. A Purely Geometric Representation of all Points in the Projective Plane. Read Oct. 28, 1899. Transactions of the American Mathematical Society, vol. 1, No. 2, pp. 182-192; April, 1900.

Cotrien, J. On the Expression of the General Equations of Hydrodynamics in Terms of Curvilinear Coordinates. Read March 27, 1897. Mathematical Magazine, vol. 1, No. 3.

Davis, E. W. Note on Special Regular Reticulations. Read (Chicago) Dec. 31, 1897. Bulletin of the American Mathematical Society, vol. 4, No. 10, pp. 529-530; July, 1898.

The Group of the Trigonometric Functions. Read (Chicago) April 1, 1899. Bulletin of the American Mathematical Society, vol. 5. No. 8, pp. 380-381; May, 1899.

Dickson, L. E. The Structure of Certain Linear Groups with Quadratic Invariants. Read Aug. 19, 1898. Proceedings of the London Mathematical Society, vol. 30, Nos. 662-664, pp. 70-98; Nov., 1898.

The Determination of the Structure of All Linear Homogeneous Groups in a Galois Field which are Defined by a Quadratic Invariant, with the Announcement of Two New Systems of Simple Groups. Read (Chicago) Dec. 30, 1898. American Journal of Mathematics, vol. 21, No. 3, pp. 193-256; July, 1899.

A New Definition of the General Abelian Linear Group. Read Feb. 25, 1899, and Aug. 26, 1899. Transactions of the American Mathematical Society, vol. 1, No. 1, pp. 91-96 ; Jan. 1900.

Concerning the Four Known Simple Linear Groups of Order 25920, with an Introduction to the Hyper-Abelian Linear Groups. Read (Chicago) April 1, 1899. Proceedings of the London Mathematical Society, vol. 31, Nos. 680-683, pp. 30-68 ; April, 1899.

Definition of the Abelian, the Two Hypoabelian, and Related Linear Groups as Quotient Groups of the Groups of Isomorphisms of Certain Elementary Groups. Read Aug. 26, 1899. Transactions of the American Mathematical Society, vol. 1, No. 1, pp. 30-38 ; Jan., 1900 . 
Canonical Form of a Linear Homogeneous Substitution in a General Galois Field. Read (Chicago) Dec. 28, 1899. American Journal of Mathematics, vol. 22, No. 2, pp. 121-137 ; April, 1900.

Proof of the Existence of the Galois Field of Order $p^{r}$ for Every Integer $r$ and Prime Number $p$. Read Dec. 28, 1899. Bulletin of the American Mathematical Society, vol. 6, No. 5, pp. 203-204 ; Feb., 1900.

Isomorphism between Certain Systems of Simple Linear Groups. Read Feb. 24, 1900. Bulletin of the American Mathematical Society, vol. 6, No. 8, pp. 323-328; May, 1900.

Proof of the Non-Isomorphism of the Simple Abelian Group on $2 m$ Indices and the Simple Orthogonal Group on $2 m+1$ Indices for $m>2$. Read Feb. 24, 1900. Quarterly Journal of Mathematics, vol. 32, No. 1, pp. 42-63; June, 1900.

Емсн, A. Circular Transformations. Read (Chicago) Jan. 1, 1897. Annals of Mathematics, 1st series, vol. 12, No. 5, pp. 141-160 ; Aug., 1898.

- Illustration of the Elliptic Integral of the First Kind by a Certain Link-Work. Read Aug. 25, 1899. Annals of Mathematics, 2d series, vol. 1, No. 2, pp. 81-92 ; Jan., 1900.

Engberg, C. C. The Cartesian Oval and the Auxiliary Parabola. Read (Chicago) Dec. 30, 1898. The Graduate Bulletin of the University of Nebraska, vol. 1, No. 1, pp. 23-34 ; A pril, 1900.

Goodspeed, E. J. The Ayer Papyrus: A Mathematical Fragment. Read (Chicago) Dec. 31, 1897. American Journal of Philology, vol. 19, No. 1, pp. 25-39; April, 1898.

Gordan, Paul. Formentheoretische Entwickelung der in Herrn White's Abhandlung über Curven dritter Ordnung enthaltenen Sätze. Read Oct. 28, 1899. Transactions of the American Mathematical Society, vol. 1, No. 1, pp. 9-13; Jan., 1900.

Goursat, E. Sur la Définition Générale des Fonctions Analytiques, d'après Cauchy. Read April 29, 1899. Transactions of the American Mathematical Society, vol. 1, No. 1, pp. 14-16 ; Jan., 1900.

Hathaway, A. S. Alternate Processes. Read Aug. 17, 1897, and (Chicago) Dec. 30, 1897. Proceedings of the Indiana Academy of Science, 1897, pp. 117-12\%.

Orthogonal Surfaces. Read (Chicago) Dec. 30, 1897. Proceedings of the Indiana Academy of Science, 1896, pp. 85-86.

HAyes, E. Note on the Folium of Descartes. Read Aug. 17, 1897. Bulletin of the American Mathematical Society, vol. 4, No. 1, p. 4; Oct., 1897.

Hedrick, E. R. On Three Dimensional Determinants. Read Feb. 25, 1899. Annals of Mathematics, 2d series, vol. 1, No. 2, pp. 49-67; Jan, 1900.

HILL, G. W. On the Extension of Delaunay's Method in the Lunar Theory to the General Problem of Planetary Motion. Read Feb. 24, 1900. Transactions of the American Mathematical Society, vol. 1, No. 2, pp. 205-242; A pril, 1900. 
Hutchinson, J. I. The Hessian of the Cubic Surface. II. Read Feb. 24, 1900. Bulletin of the American Mathematical Society, vol. 6, No. 8, pp. 328-337 ; May, 1900.

Keyser, C. J. Some Theorems in $n$ Dimensional Space. Read Dec. 29, 1897. Bulletin of the American Mathematical Society, vol. 4, No. 5, pp. 181-182; Feb., 1898.

Laves, K. The Ten Integrals of the Problem of $n$ Bodies for Forces Involving the Coordinates and Their First and Second Differentials. Read (Chicago) April 9, 1898. Astronomical Journal, vol. 19, No. 13, pp. 97-104; Oct. 8, 1898.

Ling, G. H., and Miller, G. A. A Proof that there are no Simple Groups of Order 1440, 1512, 1680, or 1800. Read Feb. 26, 1899, and Aug. 26, 1899 . American Journal of Mathematics, vol. 22, No. 1, pp. $13-26$; Jan., 1900.

LoverT, E. O. Sur les Invariants Projectifs d'un Système de $m+1$ Points dans l'Espace à $n+1$ Dimensions Read Aug. 19, 1898. Bulletin des Sciences Mathématiques, ser. 2, vol. 22, No 1, pp. 10-15; Jan , 1899.

Contact Transformations of Developable Surfaces. Read Oct. 29, 1898. Rendiconti del Circolo Matematico di Palermo, vol. 13, No. 4, pp. 210-224; July-Aug., 1899.

Contact Transformations and Optics. Read Dec. 28, 1898. Cambridge Philosophical Transactions, vol. 18, pp. 256-268 ; 1899.

Note on the Differential Invariants of Goursat and Painlevé. Read Feb. 25, 1899 . American Journal of Mathematics, vol. 22, No. 1, pp. 41-45 ; Jan., 1900.

Families of Transformations of Straight Lines into Spheres. Read Oct. 28, 1899. American Journal of Mathematics, vol. 22, No. 2, pp. 138-145 ; April, 1900.

Maclay, J. On Certain Algebraic Double Minimal Surfaces. Doctor Dissertation, Columbia University, 1899.

Maschкe, H. Beweis des Satzes dass diejenigen endlichen linearen Substitutionsgruppen, in welchen einige durchgehends verschwindende Coefficienten auftreten, intransitiv sind. Read (Chicago) Dec. 30, 1898. Mathematische Annalen, vol. 52, No. 3, pp. 363-368; July, 1899.

Note on the Unilateral Surface of Moebius. Read (Chicago) Dec. 29, 1899. Transactions of the American Mathematical Society, vol. 1, No. 1, p. 39 ; Jan., 1900.

- A New Method of Determining the Differential Parameters and Invariants of Quadratic Differential Quantities. Read (Chicago) April 14, 1900. Transactions of the American Mathematical Society, vol. 1, No. 2, pp. 197-204; April, 1900.

Metzler, W. H. (On the Excess of the Number of Combinations in a Set Which Have an Even Number of Inversions over Those Which Have an Odd Number. Read Feb. 26, 1898. American Journal of Mathematics, vol. 22, No. 1, pp. 55-59 ; Jan., 1900. 
On the Roots of a Determinantal Equation. Read (Chicago) Apr. 9,1898 . American Journal of Mathematics, vol. 21 , No. 4, pp. 367368 ; Oct., 1899.

Mrller, J. A. Concerning Certain Modular Functions of Square Rank. Read (Chicago) Dec. 28, 1899. Doctor Dissertation, The University of Chicago, 1900.

Mrller, G. A. Memoir on Substitution Groups Whose Degree Does not Exceed Eight. Read Dec. 28, 1898. American Journal of Mathemalics, vol. 21, No. 4, pp. 287-338 ; Oct., 1899.

On the Primitive Groups of Degree Seventeen. Read Feb. 25, 1899. Quarterly Journal of Mathematics, vol. 31, No. 1, pp. 49-57; 1899.

On the Simply Transitive Primitive Groups. Read Oct. 28, 1899. Bulletin of the American Mathematical Society, vol. 6, No. 3, pp. 103-104 ; Dec., 1899.

- On the Groups That are Direct Products of Subgroups. Read Aug. 26, 1899. Transactions of the American Mathematical Society, vol. 1, No. 1, pp. 66-71; Jan., 1900.

- On the Product of Two Substitutions. Read Oct. 28, 1899. American Journal of Mathematics, vol. 22, No. 2, pp. 185-190 ; April, 1900.

- Note on the Group of Isomorphisms. Read Feb. 24, 1900 . Bulletin of the American Mathematical Society, vol. 6, No. 8, pp. 337-339; May, 1900.

- See LING, G. H.

Moore, E. H. On Certain Crinkly Curves. Read Aug. 25, 1899. Transactions of the American . Wathematical Society, vol. 1, No. 1, pp. 7290 ; Jan., 1900.

More, L. T. On Fresnel's Wave Surface. Read Aug. 26, 1899. Philosophical Magazine, 5th series, vol. 49, No. 3, pp. 262-274 ; March, 1900.

Morley, F. On the Limaçons Which Possess Poncelet Polygons. Read May 25, 1895. Proceedings of the London Mathematical Society, vol. 29, No. 617, pp. 83-97; Nov., 1897.

- The Metric Geometry of the Plane $n$ Line. Read Feb. 24, 1900. Transactions of the American Mathematical Society, vol. 1, No. 2, pp. 97-115; April, 1900.

Moulton, F. R. On a Class of Particular Solutions of the Problem of Four Bodies. Read Aug. 25, 1899. Transactions of the American Mathematical Society, vol. 1, No. 1, pp. 17-29 ; Jan., 1900.

Newson, H. B. On Singular Transformations in Real Projective Groups. Read A pril 28, 1900. Bulletin of the American Mathematical Society, vol. 6 , No. 10, pp. 431-439; July, 1900.

OsGood, W. F. Beweis der Existenz einer Lösung der Differentialgleichung $\frac{d y}{d x}=(x, y)$ ohne Hinzunahme der Cauchy-Lipschitz'schen. Bedingung. Read Feb. 26, 1898. Monatshefte für Mathematik und Physik, vol. 9, No. 4, pp. 331-345 ; Oct., 1898.

Pelc, A. Evaluation of a Definite Integral. Read (Chicago) Dec. 28, 1899. Annals of Mathematics, 2d series, vol. 1, No. 3, pp. 144-146 ; April, 1900 . 
Philbrick, P. H. The True Transition Curve. Read Aug. 17, 1897. Field Manual for Railroad Engineers, John Wiley and Sons, New York, 1900.

Pinrpont, J. P. Galois' Theory of Algebraic Equations. Read Sept. 1, 1896. Annals of Mathernatics, 2d series, vol. 1, No. 3, pp. 113143 ; A pril, 1900.

Porter, M. B. Note on the Enumeration of the Roots of the Hypergeometric Series between Zero and One. Read Feb. 24, 1900. Bulletin of the American Mathematical Society, vol. 6, No. 7, pp. 280282 ; April, 1900.

PUPIN, M. I. Propagation of Long Electrical Waves. Read Feb. 25, 1899. Transactions of the American Institute of Electrical Engineers, vol. 16, No. 3, pp. 111-160; March, 1899.

REES, J. K. Results of Seven Years' Observations for Variations of Latitude and the Constant of Aberration, Made at the Columbia University Observatory. Read Feb. 24, 1900. Bulletin of the American Mathematical Society, vol. 6, No. 7, pp. 269-273 ; April, 1900. Popular Astronomy, vol. 8, No. 4, pp. 169-174 ; April, 1900.

RoE, E. D. On Symmetric Functions. Read Oct. 29, 1898. American Mathematical Monthly, vol. 6, Nos. 1, 2, 3, 4, 5, 6, pp. 1-6, 25-30, 53-58, 103-107, 129-135, 161-165 ; Jan.-June, 1899.

On the Transcendental Form of the Resultant. Read (Chicago) Dec. 28, 1899. American Mathematical Monthly, vol. 7, No. 3, pp. 59-66 ; March, 1900.

Schottenfels, I. M. On Groups of Order 8!/2. Read June 29, 1900. Bulletin of the American Mathematical Society, vol. 6, No. 10, pp. 440-443; July, 1900.

Scotr, C. A. A Proof of Noether's Fundamental Theorem. Read April 29, 1899. Mathematische Annalen, vol. 52, No. 4, pp. 593597 ; Dec., 1899.

- The Status of Imaginaries in Pure Geometry. Read Oct. 28, 1899. Bulietin of the American Mathematical Society, vol. 6, No. 4, pp. 163-168; Jan., 1900.

SNyder, V. Lines of Curvature on Annular Surfaces Having Two Spherical Directrices. Read Feb. 25, 1899. American Journal of Mathematics, vol. 22, No. 1, pp. 96-200 ; Jan., 1900.

- Geometric Construction of the Elliptic Integral of the Second Kind, and of the Weierstrass Sigma-Function. Read Aug. 26, 1899. Schilling's Modell-Katalog, Halle, 1900.

On Cyclical Quartic Surfaces in Space of $n$ Dimensions. Read Dec. 28, 1899. Bulletin of the American Mathematical Society, vol. 6, No. 5, pp. 194-198; Feb., 1900.

- On the Geometry of the Circle. Read Dec. 28, 1899. Bulletin of the American Mathematical Society, vol. 6, No. 8, pp. 319-322; May, 1900.

Stabler, E. L. A Rule for Finding the Day of the Week Corresponding to a Given Date. Read Aug. 28, 1898. Science, new series, vol. 8, No. 200, p. 594 ; Oct. 28, 1898. 
Starkweather, G. P. Non-Quaternion Number Systems Containing No Skew Units. Read April 29, 1899. American Journal of Mathematics, vol. 21, No. 4, pp. 369-386 ; Oct., 1899.

STEcker, H. F. Non-Euclidean Properties of Plane Cubics. Read Aug. 20, 1898. American Journal of Mathematics, vol. 22, No. 1, pp. 31-40 ; Jan., 1900.

TABER, H. On the Singular Transformations of Groups Generated by Infinitesimal Transformations. Read Feb. 25, 1899, and Deo. 28, 1899. Bulletin of the American Mathematical Society, vol. 6, No. 5, pp. 199-203 ; Feb., 1900.

Timerding, H. E. Some Remarks on Tetrahedral Geometry. Read June 27, 1900. Bulletin of the American Mathematical Society, vol. 6, No. 10, pp. 417-430; July, 1900.

VAN Vleck, E. B. On the Determination of a Series of Sturm's Functions by the Computation of a Single Determinant. Read Feb. 25, 1899. Arnals of Mathematics, ser. .2, vol. 1, No. 1, pp. 1-13; Oct., 1899.

Westlund, J. On a Class of Equations of Transformation. Read A ug. 19, 1898. American Journal of Mathematics, vol. 21, No. 4, pp. $339-353$; Oct., 1899.

White, H. S. Conics and Cubics Connected with a Plane Cubic by Certain Covariant Relations. Read Aug. 25, 1899. Transactions of the American Mathematical Society, vol. 1, No. 1, pp. 1-8; Jan., 1900.

Plane Cubics and Irrational Covariant Cubics. Read (Chicago) Dec. 28, 1899. Transactions of the American Mathematical Society, vol. 1, No. 2, pp. 170-181; A pril, 1900.

Wilson, E. B. Note on the Functions Satisfying the Functional Relation $\phi(x) \phi(y)=\phi(x+y)$. Read Apr. 29, 1899. Annals of Mathematics, ser. 2, vol. 1, No. 1, pp. 47-48 ; Oct., 1899.

The Decomposition of the General Collineation of Space into Three Skew Reflections. Read Oct. 28, 1899. Transactions of the American Mathematical Society, vol. 1, No. 2, pp. 193-196 ; April, 1900.

Woodward, R. S. The Century's Progress in Applied Mathematics. [Presidential Address.] Read Dec. 28, 1899. Bulletin of the American Mathematical Society, yol. 6, No. 4, pp. 133-163. Jan., 1900. Science, new series, vol. 11, No. 263, pp. 41-51; Jan. 12, 1900 ; No. 264, pp. 81-92; Jan. 19, 1900.

An Elementary Method of Integrating Certain Linear Differential Equations. Read April 28, 1900. Bulletin of the American Mathematical Society, vol. 6, No. 9, pp. 369-371 ; June, 1900. 